\title{
Chest ultrasounds and X-rays compared in patients with acute dyspnea in an Emergency Department
}

\author{
IF Martino*, G Statti, F Fancoli, C Tinelli, MA Bressan \\ From 7th WINFOCUS Italian Congress on Ultrasound in Emergency, Anaesthesiology and Critical Care \\ Lodi, Italy. 26-29 March 2014
}

\begin{abstract}
Background
Dyspnea is one of the most frequent causes of access to the Emergency Department (ED). A major challenge for the emergency physician lies in differentiating diagnosis between cardiogenic and respiratory dyspnea. Currently, the instrument mainly used for the diagnosis of acute pulmonary disease is a chest X-ray: however, chest ultrasounds (US) are proving their potential in the diagnosis of acute dyspnea.
\end{abstract}

\section{Objective}

Primary objective: to demonstrate diagnosis accuracy of chest USs using chest X-rays as a parameter for comparison in patients with acute dyspnea.

Secondary objective: to quantify savings in terms of time and resources.

\section{Patients and methods}

We enrolled all patients over the age of 18 suffering from acute dyspnea, not consequent to trauma of the chest or pneumothorax. All patients were subjected to chest USs and chest X-rays (in double blind).

\section{Results}

From January 1st to July 30th 2013, we enrolled 62 patients with acute dyspnea.

The concordance between the two methods was 97\% $(\mathrm{K}$ value $0.9=$ almost perfect $)$. Regarding the diagnosis of pleural effusion, the concordance was $90 \%$ (K value $0.8=$ substantial agreement).

Regarding the savings:

- Time: the average time necessary to obtain an X-ray is 36 minutes; time for a chest US is the time required for the visit.

\footnotetext{
* Correspondence: martino.ilaria@googlemail.com

Emergency Department, Scientific Direction, Policlinico San Matteo, Pavia, Italy
}

\section{SpringerOpen ${ }^{\circ}$}

(C) 2014 Martino et al; licensee Springer This is an Open Access article distributed under the terms of the Creative Commons Attribution License (http://creativecommons.org/licenses/by/2.0), which permits unrestricted use, distribution, and reproduction in any medium, provided the original work is properly cited.
- Costs: the average cost of an X-ray is 37 Euros. Only in 2 cases was there no match, ideally giving a saving of $€ 2220$ (60 X-rays X 37 Euros).

\section{Conclusion}

Chest USs have a high reliability for diagnosis of acute dyspnea as compared to X-rays (more sensitive than $\mathrm{X}$-rays for the diagnosis of pleural effusion). USs allow a saving in time and costs. Chest Uss should be considered an essential tool for the emergency physician.

Published: 27 August 2014

\section{References}

1. Lichtenstein D: Ultrasound in the management of thoracic disease. Crit Care Med 2007, 35:S250-S261.

2. Volpicelli $\mathrm{G}$, et al: International evidence-based recommendations for point of care lung US. Int. Care Med 2012, 38:577-591.

\section{doi:10.1186/2036-7902-6-S2-A}

Cite this article as: Martino et al:: Chest ultrasounds and X-rays compared in patients with acute dyspnea in an Emergency Department. Critical Ultrasound Journal 2014 6(Suppl 2):A1.

\section{Submit your manuscript to a SpringerOpen ${ }^{\circ}$ journal and benefit from: \\ - Convenient online submission \\ - Rigorous peer review \\ - Immediate publication on acceptance \\ - Open access: articles freely available online \\ - High visibility within the field \\ - Retaining the copyright to your article}

Submit your next manuscript at $>$ springeropen.com 